\title{
Comparing Extraction Methods for Biomarker Steroid Characterisation from Soil and Slurry
}

\author{
Amber Manley (D) Adrian L. Collins • Adrian Joynes • \\ Per-Erik Mellander • Phil Jordan
}

Received: 2 July 2020 / Accepted: 22 September 2020 / Published online: 9 October 2020

(C) The Author(s) 2020

\begin{abstract}
Clean water is a precious resource, and policies/programmes are implemented worldwide to protect and/or improve water quality. Faecal pollution can be a key contributor to water quality decline causing eutrophication through nutrient enrichment and pathogenic contamination. The robust sourcing of faecal pollutants is important to be able to target the appropriate sector and to engage managers. Biomarker technology has the potential for source confirmation, by using, for example the biomarker suite of steroids. Steroids have been used in the differentiation of human and animal faeces; however, there is no unequivocal extraction technique. Some of the methods used include (i) Soxhlet extraction, (ii) Bligh and Dyer (BD) extraction, and (iii) accelerated solvent extraction (ASE). The less costly and time intensive technique of ASE is particularly attractive, but a current research gap concerns further comparisons regarding ASE lipid extraction from soils/slurries compared with the more traditional Soxhlet and BD extractions. Accordingly, a randomised complete block experiment was implemented to assess differences between the three
\end{abstract}

A. Manley · A. L. Collins · A. Joynes

Sustainable Agriculture Sciences, Rothamsted Research, North Wyke, Okehampton EX20 2SB, UK

A. Manley · P.-E. Mellander

Agricultural Catchments Programme, Teagasc, Environment

Research Centre, Johnstown Castle, Co., Wexford, Ireland

A. Manley $(\bowtie) \cdot$ P. Jordan

School of Geography and Environmental Sciences, Ulster

University, Cromore Road, Coleraine BT52 1SA, UK

e-mail: amber.manley@rothamsted.ac.uk extraction methods, differences between the different sample types, and the interactions between these two factors. Following GC-MS, it was found that there was no significant difference between the results of the steroid extraction methods, regardless of the type of sample used, for the quantity of each steroid extracted. It was concluded that ASE could be used confidently instead of the more established steroid extraction methods, thereby delivering time and cost savings.

Keywords Lipids · ASE - Bligh and Dyer - Soxhlet . Faecal pollution
Abbreviations
BD Bligh and Dyer
ASE Accelerated solvent extraction
$\mathrm{N} \quad$ Nitrogen
P Phosphorus
IMS Industrial methylated spirit
DCM Dichloromethane
TLE Total lipid extract
BDS Bligh and Dyer solvent
PCA Principal component analysis
PC Principal component
CVA Canonical variate analysis

\section{Introduction}

Faecal matter transferred through and exported from catchments, originating from various point and diffuse 
sources, can be a vector for phosphorus (P) and nitrogen $(\mathrm{N})$ causing eutrophication in water bodies and causing human health pressures due to associated pathogens (Jang et al. 2017). Determining the source proportions of faecal matter is challenging and biomarker technologies have been applied in recent years to address this (Unno et al. 2018). Biochemical methods have also been shown to have potential applications in tracing nutrients, organic matter and fine-grained sediments from these sources, and particularly in agricultural catchments (Mudge and Duce 2005; Arnscheidt et al. 2007).

Steroids are a potential lipid biomarker suite used in previous studies ( $\Delta 5$-sterols, stanols, stanones) (Prost et al. 2018) and are an important class of organic molecules present in most cells (Huang and Meinschein 1976). The ability to use steroids as biomarkers of faecal pollution was developed by Leeming et al. (1994, 1996, 1997, 1998) and used as robust discriminators between human and herbivorous faecal matter based on their differing distributions. Using this fingerprinting approach, steroids have been used to confirm sources of faecal contamination including wastewater outputs (Grimalt et al. 1990; Leeming et al. 1997; Mudge et al. 1999), farm land slurry applications (Jardé et al. 2009), or animal waste runoff (Nash et al. 2005; Tyagi et al. 2007). Despite this utility, there is no unequivocal universally applied technique for isolating lipid biomarkers prior to mass spectrometry analysis. Instead, a wide range of extraction procedures is applied in contemporary practice, including Soxhlet extraction, Bligh and Dyer (BD) extraction, and accelerated solvent extraction (ASE). An overview is provided here.

The Soxhlet extractor was developed by Franz von Soxhlet in 1879 as laboratory equipment to be used in the extraction of lipids and has become one of the most well-established lipid extraction techniques used (Lyons et al. 2015; Kolm et al. 2018). In fact, the Soxhlet extraction method has been used as the primary reference to which other, newer extraction methods have been compared over the several decades (Luque de Castro and Priego-Capote 2010). Whilst being a robust and well-established technique and has other advantages, the method has disadvantages. One advantage is the continuous cycle that the solvent undergoes (evaporation-condensation) that brings the solid sample in contact with fresh solvent and facilitates extraction. Secondly, the equipment to perform Soxhlet extraction is relatively cheap (excluding the solvent costs). Thirdly, the methodology is quite simple and requires little training (Luque de Castro and Priego-Capote 2010). The main disadvantages include lengthy extraction times and larger extractant sizes that result in more waste (which has both economic and environmental implications). Difficulties with automation and a lack of agitation are other disadvantages as well as the potential for thermal decomposition of the sample due to the high temperatures used (Luque de Castro and Priego-Capote 2010).

There have been various alterations made to conventional Soxhlet extraction over the years that aim to address the limitations. These include high pressure Soxhlet extraction wherein high pressure is achieved by placing the extractor in a cylindrical autoclave (Ndiomu and Simpson 1988) or by the use of supercritical fluid-Soxhlet extractors (Luque de Castro and Priego-Capote 2010), ultrasound-assisted Soxhlet extraction (makes use of an ultrasonic probe being added to the sample chamber; Luque-Garcia and De Castro 2004), and microwave-assisted Soxhlet extraction (use of microwave irradiation on the sample chamber) (Luque de Castro and Priego-Capote 2010). Each acts on the advantages and disadvantages of conventional Soxhlet extraction, but adds complexity, cost, and technical training.

Another similarly well-established method is the BD extraction. The BD method was developed in 1959 (Bligh and Dyer 1959) for extracting lipids, and has become the standard procedure to separate total lipid fractions from samples. It is both less time consuming and less costly than Soxhlet extraction. BD has been used in several areas such as in hospitals, pharmaceuticals, and food studies (Breil et al. 2017). However, BD makes use of chemicals like chloroform (toxic and carcinogenic) giving the method a safety disadvantage that makes it difficult for large scale use (Breil et al. 2016). As such, there are some limitations to its applicability (Hussain et al. 2014; Breil et al. 2017). Any improvements to BD have focused mostly on replacing the solvents used in the original method to less dangerous alternatives (Grima et al. 1994; Lee et al. 1998; Sheng et al. 2011; Caprioli et al. 2016). However, the methods employed remain toxic to both humans and the environment (though lessened using fume cupboards). Various methodological alterations have also been investigated to help improve BD. Among them are the use of ultrasound, microwaves, 
heat, pressure, or beads (Axelsson and Gentili 2014; Berndmeyer et al. 2014; Ryckebosch et al. 2012; Teo and Idris 2014; Medina et al. 2015; Lee et al. 2010; Cescut et al. 2011). Whilst both Soxhlet and BD methods have improved over time, both methods are still timely and work intensive.

A promising alternative is the ASE technique (Richter et al. 1996; Jansen et al. 2006). In summary, ASE extracts samples under elevated temperature, whilst elevated pressure ensures that volatile extractants remain liquid. ASE can be completely automated; it employs very small extractant volumes (normally 5-30 $\mathrm{mL}$ ) and has typical extraction times of less than an hour (Richter et al. 1996; Jansen et al. 2006). As such, the technique has the potential to overcome the main disadvantages of both Soxhlet and BD extraction methods. This reduction in labour time and solvent can result in ASE being cheaper to use per sample than both alternative methods. However, ASE requires specific instrumentation unlike Soxhlet and BD (that uses glassware) that can cost approximately $£ 30,000$ (cost estimated in 2019). In some circumstances, compared with these conventional methods, modern ASE methods have been able to yield equivalent, if not better, extraction efficacies (Jansen et al. 2006; Balasubramanian et al. 2013). However, whilst the use of ASE to extract organic contaminants from media such as soils is now reasonably well-established (Giergielewicz-Mozajska et al. 2001; Chitescu et al. 2012), its application to the specific extraction of lipids from other solid matter has received less attention. A comparison of ASE with more established techniques is important if ASE is to be used in biomarker studies that require mass spectrometry analysis on potentially high sample numbers. This is because differences in extraction efficiencies for several types of lipids between ASE and other techniques would lead to a difference in the composition of the biomarker signature that is obtained.

Therefore, the aim of the current study was to examine and compare the efficiency of ASE with more established Soxhlet extraction and BD extraction methods, for extracting typical lipid biomarkers, including steroids, from both animal slurry and soil samples. These two biomarker sources, individually and in combination, were characterised here as potential diffuse sources of faecal matter in agricultural catchments.

\section{Materials and Methods}

\subsection{Study Area and Experimental Design}

Higher Wheaty, a grazed grassland field at Rothamsted Research North Wyke, UK, was used in this experiment. This field has been used for livestock grazing and has had applications of fertilisers/herbicides in the last four years prior to sampling. Soil belongs to the Halstow soil series - a clayey typical noncalcareous pelosol in head from clay shale. Preliminary laboratory test results of the soil in 2018, shown in Table 1, indicate that the $\mathrm{pH}$ and $\mathrm{P}$ levels are higher than expected, but this is likely due to a large application of $\mathrm{P}_{2} \mathrm{O}_{5}$ on to the field in 2016. The cattle slurry used in this experiment was collected from an open air slurry lagoon on a nearby dairy farm in SW England on a grazed grassland system with winter housing of animals.

A randomised complete block design was created to assess for differences between the extraction methods, differences between the different sample types, and the interactions between these two factors. Three types of sample were collected for this study, i.e. slurry (Slurry), topsoil of the plot to a depth of $2 \mathrm{~cm}$ prior to the slurry application (Soil), and the topsoil $24 \mathrm{~h}$ after the slurry application (Both). This design utilised four $0.6 \mathrm{~m}^{2}$ plots to act as replicates for each sample type taken from different areas of the same field, as shown in Fig. 1. These plots were each split in half with soil sampled from the downhill half and slurry spread only on the uphill half then sampled $24 \mathrm{~h}$ later. These four replicates of each sample type were then divided into three subsamples each; one to be analysed for each extraction method per replicate, per sample type, as shown in Fig. 2. This was designed so replicates would contain relatively homogenous material and so provide a fair comparison of the three extraction methods. As the samples taken from each plot were linked (soil pairs of before and after slurry application), the plots could be considered a block of nine samples (three sample 'Types' to be analysed by three different steroid extraction 'Methods').

\subsection{Chemical Preparation and Extraction Methods}

All equipment used in the study was washed thoroughly prior to use. Aluminium foil and containers were muffle furnaced $\left(450{ }^{\circ} \mathrm{C}\right.$ for at least $\left.4 \mathrm{~h}\right)$ to remove organic contaminants before use. All glassware was washed 
Table 1 Preliminary laboratory test results for the Higher Wheaty study field, Rothamsted Research North Wyke, Devon, completed in April 2018. Soil P (and K, Mg) is based on the Olsen extraction

\begin{tabular}{llllllll}
\hline Area (ha) & $\mathrm{pH}$ value & $\mathrm{P}$ (index) & $\mathrm{P}(\mathrm{mg} / \mathrm{L})$ & $\mathrm{K}($ index $)$ & $\mathrm{K}(\mathrm{mg} / \mathrm{L})$ & $\mathrm{Mg}($ index $)$ & $\mathrm{Mg}(\mathrm{mg} / \mathrm{L})$ \\
\hline 0.99 & 6.9 & 3 & 27.4 & 1 & 108 & 2 & 97 \\
\hline
\end{tabular}

method and places the soil at just above the agronomic optimum (index $3>26 \mathrm{mg} / \mathrm{L}$ ) thoroughly and rinsed in acetone before use. The custom-made $2 \mathrm{~cm}$ depth soil corer was washed in Virkon disinfectant, MilliQ water, and acetone prior to use. Between samplings in the field, equipment was washed with Virkon disinfectant and MilliQ water to minimise contamination. Sieves and grinders were similarly washed thoroughly with Microsol ${ }^{4}$ disinfectant, MilliQ water, and grinders also received an industrial methylated spirit (IMS) wash both prior to, and between, sample use to avoid cross-contamination.

For each block, cores were taken and loosely sealed in an aluminium foil container. Following soil sampling, $610 \mathrm{~mL}$ of slurry was applied manually to the un-cored half of the block at a rate of $3.3 \mathrm{~L} / \mathrm{m}^{2}$. This rate is to simulate a typical slurry application rate of 33 cubic metres of slurry per hectare (Brennan et al. 2012). The

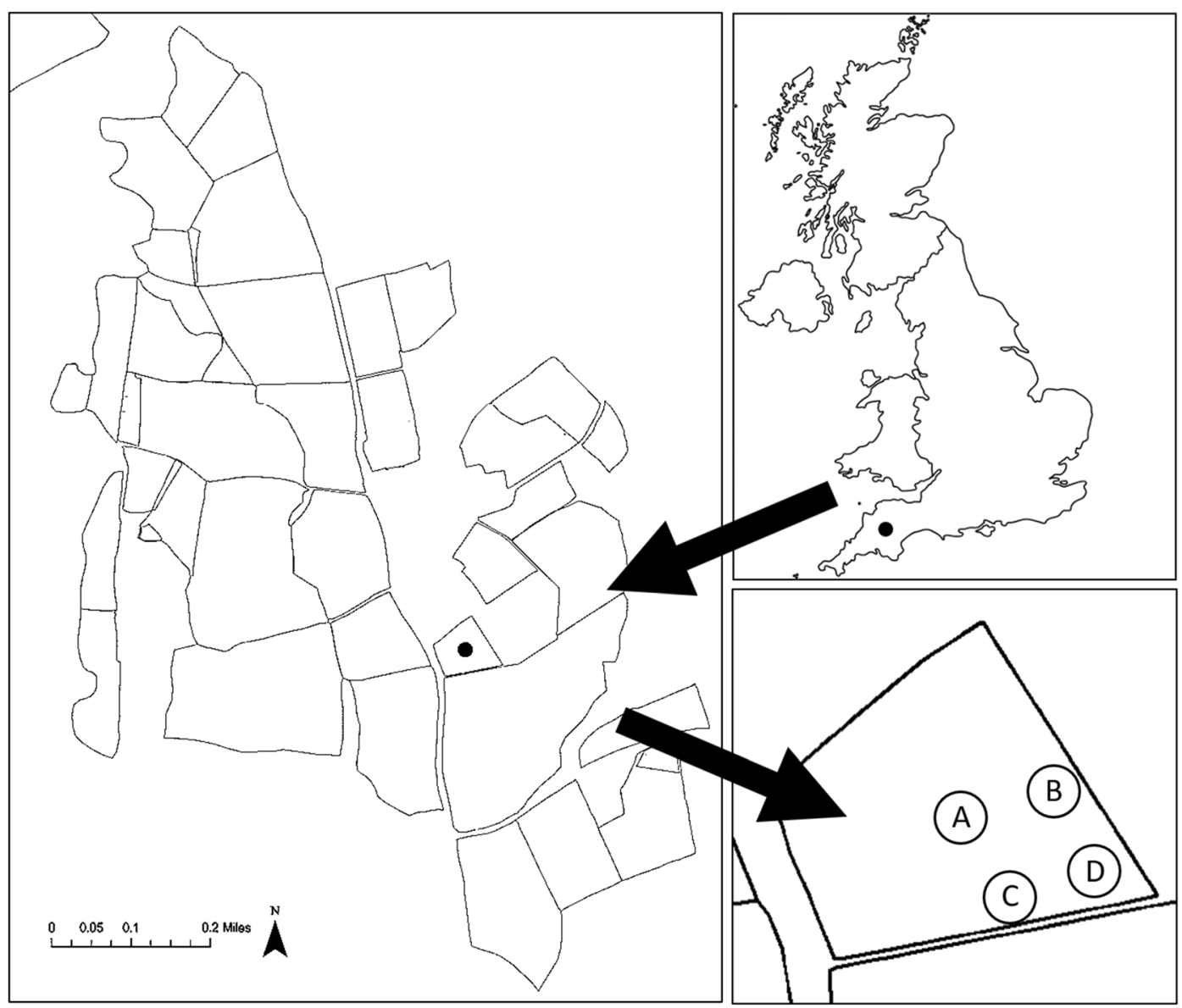

Fig. 1 An image of the sampling sites in Higher Wheaty field, Rothamsted Research North Wyke, UK (black circles marked on the maps). Samples were taken from four sites in the study field. These sites comprised areas of the field where some natural variation would be expected. Plot A is mid-field, so most likely exposed to higher levels of animal wastes in the past. Plot B is by the edge of the field where mostly grass grows. Plot $\mathrm{C}$ is similarly on the edge of the field but has a mixture of grass and weeds growing. Plot $\mathrm{D}$ is by the gate to the field, so the soil is likely to be more compacted. This was done to provide a wide range of values for checking agreement regarding differences between methods and sample types 


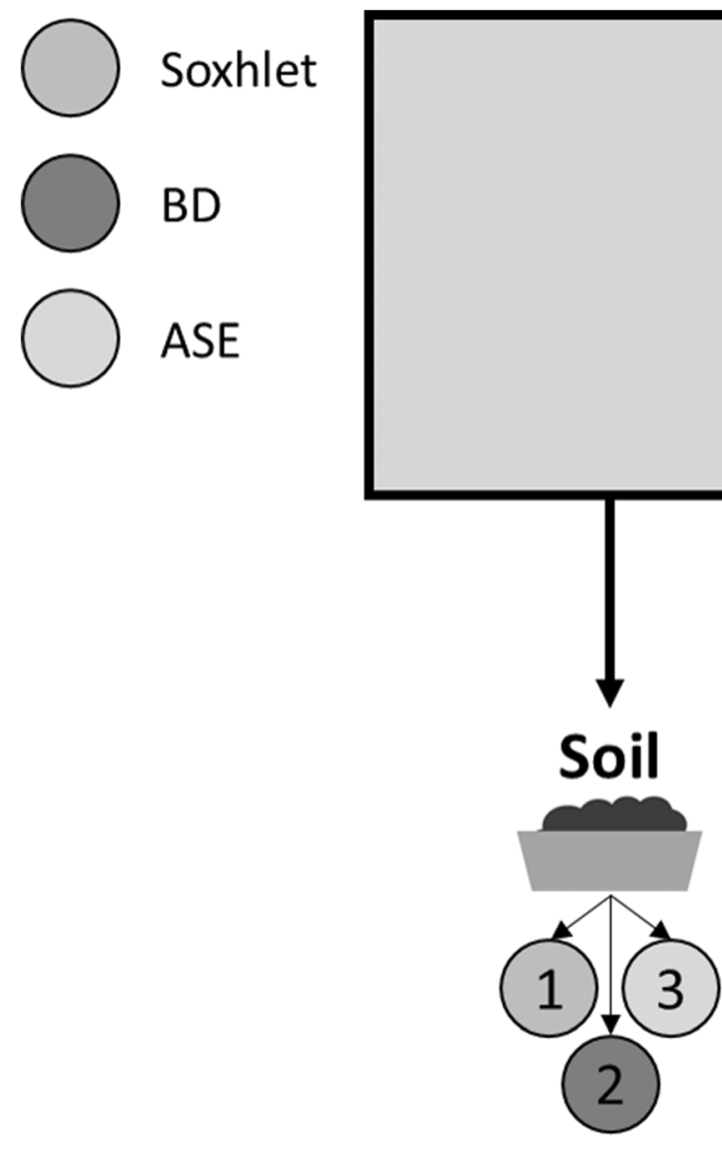

Fig. 2 A visual representation of the plots and sampling used in this experiment. The non-patterned side of the plot was on the most downhill side of the entire plot to prevent the soil sampling from affecting later sampling. Only soil came from this side. The patterned side was on the most uphill side of the plot and had $610 \mathrm{~mL}$ of slurry applied and was left for $24 \mathrm{~h}$ before sampling.

slurry samples remaining were saved and transferred to an aluminium container in the laboratory. The samples were then uncovered and placed in an oven set at $30{ }^{\circ} \mathrm{C}$ to dry. After $24 \mathrm{~h}$, the soil with slurry (both) samples were collected and then placed in the same oven set at $30{ }^{\circ} \mathrm{C}$ to dry.

All samples were considered dry once a constant weight was achieved. Once dry, samples were sieved to $2 \mathrm{~mm}$ to remove any large debris, finely milled, and stored in glass vials. Samples were analysed as block composites (i.e. all samples from one block at a time) to account for any possible variation arising from longer latency periods between storage and analysis. Each block analysis amounted to three samples split between the three extraction methods (three extractions to be

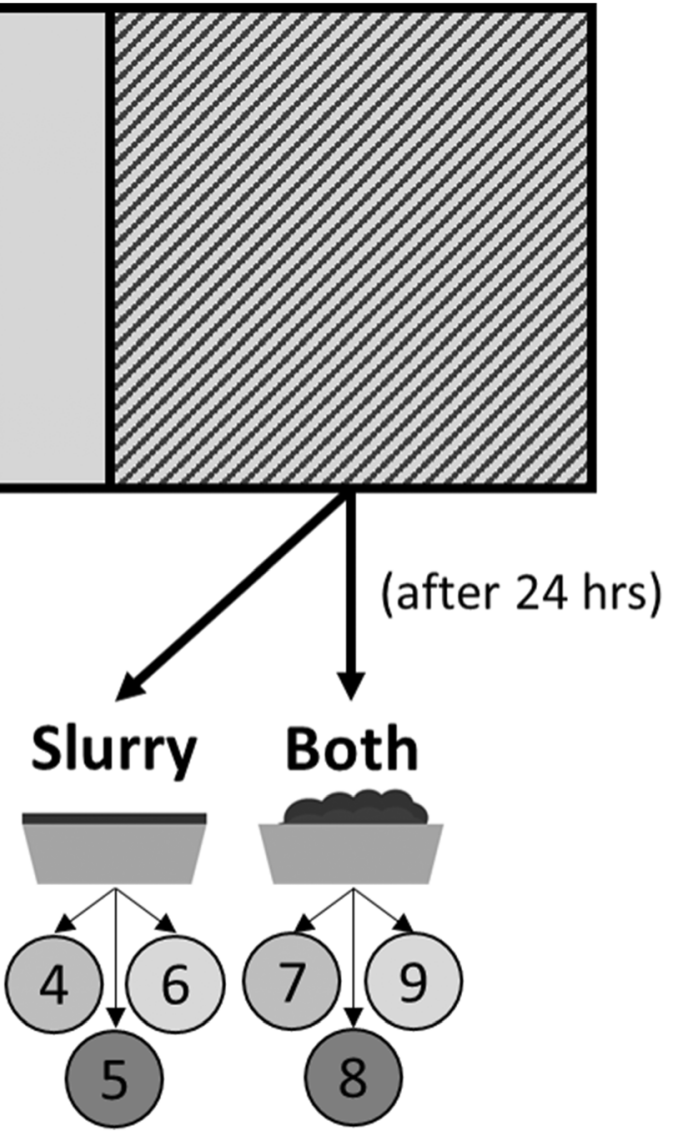

Slurry and both (soil with an application of slurry) was taken from this side. Each of these sample types were extracted using all three extraction methods. This made it so that each plot (A, B, C, and D from Fig. 1) had nine samples in a block, i.e. A1-9, B1-9, C1-9 and D1-9

completed per method, per block, equalling nine samples/analyses per block), shown in Fig. 2. Each extraction method commenced at the same time. For all extractions, $5 \mathrm{~g}$ of soil/both was used and $0.5 \mathrm{~g}$ of slurry (Leeming et al. 1996). These values were chosen to ensure that the optimum amount of steroid was extracted for analyses (with slurry requiring much less sample due to the inherently greater levels of steroids). The internal standard ( $100 \mu \mathrm{L}$ of $0.2 \mathrm{mg} / \mathrm{mL} 5 \beta$-pregan$3 \alpha$-ol) that the steroids were quantified against (concentrations relative to the standard) was placed directly with the soil/slurry sample in the thimble/vial/cell. Each batch of extractions had analytical blanks that were analysed following the same procedure as the samples to check for contamination. For this purpose, the internal 
standard was added to an empty pre-cleaned Soxhlet thimble, BD solvents, and empty ASE cell with no sample.

\subsection{Soxhlet Extraction}

Prior to extraction, the cellulose Soxhlet thimbles and cotton wool tops used to contain the samples in the extraction chamber were cleaned by pre-extracting with $250 \mathrm{~mL}$ of dichloromethane (DCM):acetone (9:1) for at least $6 \mathrm{~h}$ in the Soxhlet apparatus. The thimble was then removed and allowed to dry. The methodology for extraction is described in Puttock et al. (2014) and was used by Norris et al. (2013). A thimble containing the sample (topped with cotton wool) and the internal standard was placed in the extraction chamber and extracted with $250 \mathrm{~mL}$ of DCM:acetone, (9:1) for $24 \mathrm{~h}$. After extraction, the total lipid extract (TLE) was rotary evaporated, re-suspended, and transferred to a vial in $3 \times$ $2 \mathrm{~mL}$ of DCM:acetone (1:1) and finally evaporated at $37{ }^{\circ} \mathrm{C}$ under a gentle stream of $\mathrm{N}_{2}$.

\subsection{Bligh and Dyer Extraction}

All the solvents required for BD extraction were prepared just before use. Extraction began by adding $10 \mathrm{~mL}$ of the BD solvent (BDS:methanol, chloroform, and buffered water) and the internal standard to the sample in a culture tube. This was then vortexed, ultrasonicated for $15 \mathrm{~min}$, centrifuged at $2500 \mathrm{rpm}$ for $5 \mathrm{mins}$, and then the supernatant collected. This was repeated three more times (using $5 \mathrm{~mL}$, then $3 \mathrm{~mL}$ twice BDS instead). After this, $5 \mathrm{~mL}$ of chloroform and $5 \mathrm{~mL}$ of DCM extracted water was added to the supernatant. This was then vortexed, centrifuged ( $2500 \mathrm{rpm}$ for $5 \mathrm{~min}$ ), and then the organic phase collected. This was repeated three times (except for additional DCM extracted water and using $3 \mathrm{~mL}$ of chloroform instead). After extraction, the TLE was rotary evaporated, re-suspended in $3 \times 1 \mathrm{~mL}$ of DCM:acetone $(1: 1)$ and transferred to a vial. Any water was removed from the extract by running it through a drying column (Pasteur pipette plugged with Soxhlet cleaned cotton wool and filled with dried sodium sulphate). The column was washed with $3 \mathrm{~mL}$ of DCM:acetone (1:1) prior to the addition of the extract. The extract was then chased by $1 \mathrm{~mL}$ of DCM:acetone (1:1), collected with the sample, and then evaporated under a gentle stream of $\mathrm{N}_{2}$.

\subsection{Accelerated Solvent Extraction}

A Dionex ASE 350 (Thermo Scientific) was used in this study. Firstly, the stainless steel ASE cells were cleaned by being rinsed in DCM and then allowed to dry. A cellulose cell filter $(27 \mathrm{~mm})$ was then placed in the centre of the PEEK ring and pressed inside. The sample was then placed in the cell along with the internal standards. A solvent mixture of DCM:acetone $(9: 1)$ was used. The automatic extraction process comprised the following steps: (i) extraction vessels with biomass samples were loaded into the extractor; (ii) cells were filled with solvents up to a pressure of $1500 \mathrm{kPa}$; (iii) extraction vessels were heated for $5 \mathrm{~min}$; (iv) two static cycles of each $5 \mathrm{~min}$; (v) the vessel was rinsed using extraction solvent; and (vi) solvent was purged from the vessel with $\mathrm{N}_{2}$ gas for $100 \mathrm{~s}$. The extracts were then retained in $60 \mathrm{~mL}$ collection vials. After extraction, the TLE was rotary evaporated, re-suspended in $3 \times 2 \mathrm{~mL}$ of DCM:acetone (1:1), transferred to a vial and finally evaporated under a gentle stream of $\mathrm{N}_{2}$.

\subsection{Analyses Following Extraction}

To quantify the steroids, extracts were saponified to break any ester bonds and free all alcohols in the samples. This was performed using $2 \mathrm{~mL}$ of $5 \mathrm{M}$ potassium hydroxide in $90 \%$ methanol and heated at $100{ }^{\circ} \mathrm{C}$ for $1 \mathrm{~h}$. Once cooled, $2 \mathrm{~mL}$ of DCM extracted water was added to the organic extract, which was then acidified using $6 \mathrm{M}$ hydrochloric acid. Saponified organics were then extracted into chloroform $(3 \times 2 \mathrm{~mL})$, combined, and blown down. All extracts then underwent drying and fractionation (consequently) in columns using glass Pasteur pipettes, cleaned cotton wool (to plug), and $5 \mathrm{~cm}$ of either activated sodium sulphate (drying column) or activated silica gel (flash column). Both types of column were cleaned using DCM prior to sample addition. To elute the extracts, $1 \mathrm{~mL}$ of DCM was added to drying columns and $5 \mathrm{~mL}$ of DCM, then $5 \mathrm{~mL}$ of DCM:methanol (1:1) (second fraction containing the steroids) to the flash columns. The extracts were collected and dried under a gentle flux of nitrogen.

Fractionated extracts were derivatised by silylation to improve the chromatography during GC-MS analysis. This was done by adding $50 \mu \mathrm{L}$ of derivatizing agent (N,O-bis(trimethylsilyl)trifluoroacetamide [BSTFA] + trimethylchlorosilane [TMCS]) to samples which were then placed in a heating block at $70{ }^{\circ} \mathrm{C}$ for $1 \mathrm{~h}$. Extracts 
were cooled and dried under a gentle flux of nitrogen. For analysis, extracts were suspended in $75 \mu \mathrm{L}$ of hexane and transferred to a GC-MS vial ready for analysis. The samples were analysed by a methodology derived from Bull et al. (2003) using an Agilent Technologies 6890GC/5973N GC-MS with 7683 autosampler. The samples were separated on an Agilent HP-5 ms, $30 \mathrm{~m} \times$ $250 \mu \mathrm{m} \times 0.25 \mu \mathrm{m}$ column with an oven temperature programme as follows: hold for $1 \mathrm{~min}$ at $40^{\circ} \mathrm{C}$, then increase from $40{ }^{\circ} \mathrm{C}$ to $230^{\circ} \mathrm{C}$ at a rate of $20^{\circ} \mathrm{C} \mathrm{min}^{-1}$, then to $300{ }^{\circ} \mathrm{C}$ at a rate of $2{ }^{\circ} \mathrm{C} \mathrm{min}{ }^{-1}$, and finally hold for $15 \mathrm{~min}$. The source was at $230^{\circ} \mathrm{C}$ and quadrupole at $150{ }^{\circ} \mathrm{C}$, with scanning from $\mathrm{m} / \mathrm{z} 29-550$ at electron voltage $70 \mathrm{eV}$. The total ion count (TIC) data were acquired and analysed using Agilent Chemstation software. The biomarkers were identified by using known characteristic spectra and comparing with those in the National Institute of Standards spectral library (NIST, US Gov.). The TIC data were quantified against their relevant internal standard and had a detection limit of $0.3 \mu \mathrm{g} / \mathrm{g}$. The internal standard here is used specifically to determine the analyte concentration and not to monitor the internal standard recovery.

\subsection{Statistical Analyses}

To compare the extraction methods, the data were analysed in Genstat 19. Any values of 0 were due to the steroidal level being below the level of detection. As such, to continue with statistical analyses, these values were changed to $0.15 \mu \mathrm{g} / \mathrm{g}$ (the value halfway between 0 and the detection limit). Due to innate differences between the samples, the data were log transformed prior to all analyses. For ANOVA, steroids were compared using the block number and sample and sub-sample number as a block, and the method used and the type of sample as a treatment. Multivariate analysis was also completed to simultaneously consider the differences between treatments across the variables. Principal component analysis (PCA) was then performed to assess the variation in the data using the correlation matrix. This was followed by canonical variate analysis to identify the key variables contributing to these differences, using both method and sample type individually as grouping factors. The significance level for all statistical tests was 0.05 and the degrees of freedom for all tests of type is $F_{2,6}$, for method is $F_{2,18}$, and for type method is $F_{4,18}$.

\section{Results}

The steroids identified in this study are presented in Table 2 together with their systematic and trivial names and class. A total of 15 steroids were identified in the 12 slurry, soil, and both samples. This includes the precursor steroid cholesterol and key faecal biomarkers coprostanol and 24-ethyl-coprostanol. In summary, there were five derivatives of cholesterol including the precursor itself, one $\mathrm{C} 27$ bile acid/alcohol/derivative, seven stigmasterols/C24-ethyl derivatives, and two ergosterols/C24-methyl derivatives.

The cattle slurry used in this study on average contained a total of $3500 \mu \mathrm{g} / \mathrm{g}$ of steroids, soil $30 \mu \mathrm{g} /$ $\mathrm{g}$, and both $35 \mu \mathrm{g} / \mathrm{g}$. In general, the slurry samples contained higher quantities of each steroid identified than in the soil or both samples (Table 3). The predominant steroids in the slurry samples were 24-ethylcoprostanol and epi-24-ethyl-coprostanol (by at least 3 times the next largest). The steroids, $\beta$-sitosterol and stigmastanol, were predominant in soil and both samples ( 2 and 6 times, respectively).

Whilst the steroid profiles of the soil and both samples were similar, there were three steroids that varied significantly between them. The quantity of coprostanol was almost twice as much in both than in soil samples. The steroid campesterol was not identified within slurry samples in three of the four blocks. Soil and both samples contained campesterol in all blocks. $5 \beta$-Campestanol was not found or only in trace amounts in three of the blocks for both and soil sample types $(>0.5 \mu \mathrm{g} / \mathrm{g})$. In both instances, the block where campesterol (within slurry) and $5 \beta$-campestanol (in soil and both) were taken by the study field gate (Fig. 1).

Following ANOVA on the data, it was shown that all steroids showed a significant difference $(P \leq 0.05)$ regarding sample type (Table 4). The ANOVA for the steroids showed there to be no statistically significant difference $(P=\leq 0.05)$ between the method used to analyse the samples in all steroids except one (stigmastanol). This steroid showed a significant difference $(P=<0.001)$ between the amount of sample obtained between methods (Table 4 ). There was often considerable variation between the methods within these latter two types, whereas there was very little variation between methods for slurry (but the variation was still small, hence the non-significant interactions) (Table 4). Furthermore, there was no significant interaction effect between sample type and method except 
Table 2 A list of the steroids identified in the samples, with both common and systematic names, formula, chemical class, and subclass according to the LIPID MAPS initiative (Fahy et al. 2009). ST01, sterol; ST04, bile acids and derivatives; ST0101, cholesterol and derivatives; ST0403, C27 bile acids, alcohols, and derivatives; ST0104, stigmasterols and C24-ethyl derivatives; ST0103, ergosterols and C24-methyl derivatives. A $x^{*}$ by the name of the steroid indicates that it was not found on the database and thus interpreted separately using the same categories

\begin{tabular}{|c|c|c|c|c|}
\hline Common name & Systematic name & Formula & Main class & Sub class \\
\hline Coprostanol & $5 \beta$-Cholestan-3 $\beta$-ol & $\mathrm{C}_{27} \mathrm{H}_{48} \mathrm{O}$ & ST01 & ST0101 \\
\hline Epi-Coprostanol & $5 \beta$-Cholestan- $3 \alpha$-ol & $\mathrm{C}_{27} \mathrm{H}_{48} \mathrm{O}$ & ST04 & ST0403 \\
\hline Cholesterol & Cholest-5-en-3 $\beta$-ol & $\mathrm{C}_{27} \mathrm{H}_{46} \mathrm{O}$ & ST01 & ST0101 \\
\hline $5 \alpha$-Cholestanol & $5 \alpha$-Cholestan-3 $\beta$-ol & $\mathrm{C}_{27} \mathrm{H}_{48} \mathrm{O}$ & ST01 & ST0101 \\
\hline $5 \beta$-Campestanol* & $24 \alpha$-Methyl- $5 \beta$-cholestan-3 $\beta$-ol & $\mathrm{C}_{28} \mathrm{H}_{50} \mathrm{O}$ & ST01 & ST0104 \\
\hline Epi-5ß-Campestanol* & $24 \alpha$-Methyl- $5 \beta$-cholestan- $3 \alpha$-ol & $\mathrm{C}_{28} \mathrm{H}_{50} \mathrm{O}$ & ST01 & ST0104 \\
\hline 24-Ethyl coprostenol* & $24 \beta$-Ethyl- $\Delta 22$-coprostenol & $\mathrm{C}_{32} \mathrm{H}_{58} \mathrm{OSi}$ & ST01 & ST0101 \\
\hline Epi-24-ethyl coprostenol* & $24 \alpha$-Ethyl- $\Delta 22$-coprostenol & $\mathrm{C}_{32} \mathrm{H}_{58} \mathrm{OSi}$ & ST01 & ST0101 \\
\hline 24-Ethyl-coprostanol & $5 \beta$-Stigmastanol & $\mathrm{C}_{29} \mathrm{H}_{52} \mathrm{O}$ & ST01 & ST0104 \\
\hline Epi-24-ethyl-coprostanol & Epi-5 $\beta$-Stigmastanol & $\mathrm{C}_{29} \mathrm{H}_{52} \mathrm{O}$ & ST01 & ST0104 \\
\hline Campesterol & Campest-5-en-3 $\beta$-ol & $\mathrm{C}_{28} \mathrm{H}_{48} \mathrm{O}$ & ST01 & ST0103 \\
\hline Campestanol & $5 \alpha$-Campestan-3 $\beta$-ol & $\mathrm{C}_{28} \mathrm{H}_{50} \mathrm{O}$ & ST01 & ST0103 \\
\hline Stigmasterol & Stigmasta-5,22E-dien-3 $\beta$-ol & $\mathrm{C}_{29} \mathrm{H}_{48} \mathrm{O}$ & ST01 & ST0104 \\
\hline$\beta$-Sitosterol & $\begin{array}{l}\text { (8S,9S,10R,13R,14S,17R) } \\
\text {-17-[(1R,4R)-4-Ethyl-1,5-dimethyl-hexyl] } \\
\text {-10,13-dimethyl-2,3,4,7,8,9,11,12,14,15,16,17- } \\
\text { dodecahydro-1H-cyclopenta[a]phenanthren-3-ol }\end{array}$ & $\mathrm{C}_{29} \mathrm{H}_{50} \mathrm{O}$ & ST01 & ST0104 \\
\hline Stigmastanol & $5 \alpha$-Stigmastan- $3 \beta$-ol & $\mathrm{C}_{29} \mathrm{H}_{52} \mathrm{O}$ & ST01 & ST0104 \\
\hline
\end{tabular}

for in Epi-24-ethyl-coprostanol (Table 4). However, when block 1 (that contained unusually low values compared with the other blocks for this steroid) were removed and the ANOVA re-rerun, the mean values remained largely unchanged and the $F$ values became 0.002 (type), 0.228 (method), and 0.079 (interaction).

To further investigate the relationships between the methods or types used, PCA was performed. The first 2 principal components (PC) explained $96.34 \%$ of the total variation present across all the steroids (further PCs were not included as their contribution was small). The loadings in the PCA output (Table 5) indicate the importance of the different variables with regards to the overall variability. PC1 is the linear combination (a weighted sum) of the variables that explains the largest proportion of the variation in the data. Similarly, PC2 explains the largest amount of the remaining variation after PC1 has been identified. The loadings for each PC and steroid are illustrated in Fig. 3. Most of the steroids contributed to PC1 and campesterol the most to PC2. The first component clearly separates the slurry type from the other two types, with almost all steroids contributing to the separation, even campesterol, though here, the difference is in the opposite direction (slurry less than the other two types). From the PC scores, the first three observations in each set of nine are clearly those with positive values of the first component; these are all slurry samples (right hand side of the biplot). There are two points in Fig. 3 in the upper right quadrant that are separate from the other slurry samples. These points have lower levels of 24-ethyl-coprostanol and much higher levels of campesterol than other slurry samples. Similarly, there are three soil samples in the lower left hand quadrant of Fig. 3 that are separate from the groupings. All these points have twice as much coprostanol than other soil samples. There is also a distinct sub-group of six points to the right of the left hand sub-set; these are the soil and both sample types from the fourth block (by the study field gate shown in Fig. 1). These samples all contain higher levels of steroids than the other blocks: 10 times as much 24-ethylcoprostanol, 5 times as much epi-24-ethyl-coprostanol, and 3 times as much campestanol.

The results for the canonical variate analysis (CVA) regarding method suggest a weak discrimination between the three groups, and this is clearly seen in 
Table 3 Steroidal means for the treatment combinations ( $\mu \mathrm{g} / \mathrm{g})$, together with their standard error of differences (SED); $0.3 \mu \mathrm{g} / \mathrm{g}$ represents the detection limit

\begin{tabular}{|c|c|c|c|c|c|c|}
\hline \multirow[t]{2}{*}{ Steroid } & \multirow[t]{2}{*}{ Method } & \multicolumn{3}{|c|}{ Type means } & \multirow[t]{2}{*}{ Type method SED } & \multirow{2}{*}{$\begin{array}{l}\text { SED except when comparing means } \\
\text { with the same level(s) of type }\end{array}$} \\
\hline & & Slurry & Soil & Both & & \\
\hline \multirow[t]{3}{*}{ Coprostanol } & ASE & 285.71 & 0.75 & 0.69 & \multirow[t]{3}{*}{0.24} & \multirow[t]{3}{*}{0.23} \\
\hline & $\mathrm{BD}$ & 290.70 & 0.47 & 1.00 & & \\
\hline & Sox & 294.55 & 0.16 & 0.66 & & \\
\hline \multirow[t]{3}{*}{ Epi-Coprostanol } & ASE & 70.92 & 0.23 & 0.22 & \multirow[t]{3}{*}{0.20} & \multirow[t]{3}{*}{0.14} \\
\hline & $\mathrm{BD}$ & 66.73 & 0.17 & 0.37 & & \\
\hline & Sox & 75.50 & 0.10 & 0.31 & & \\
\hline \multirow[t]{3}{*}{ Cholesterol } & ASE & 159.70 & 2.26 & 1.36 & \multirow[t]{3}{*}{0.23} & \multirow[t]{3}{*}{0.26} \\
\hline & $\mathrm{BD}$ & 138.07 & 2.18 & 1.33 & & \\
\hline & Sox & 171.27 & 1.79 & 4.01 & & \\
\hline \multirow[t]{3}{*}{$5 \alpha$-Cholestanol } & ASE & 193.97 & 0.67 & 0.87 & \multirow[t]{3}{*}{0.13} & \multirow[t]{3}{*}{0.09} \\
\hline & $\mathrm{BD}$ & 194.20 & 0.59 & 1.03 & & \\
\hline & Sox & 149.06 & 0.59 & 0.89 & & \\
\hline \multirow[t]{3}{*}{$5 \beta$-Campestanol } & ASE & 54.90 & 0.24 & 0.13 & \multirow[t]{3}{*}{0.30} & \multirow[t]{3}{*}{0.19} \\
\hline & $\mathrm{BD}$ & 42.06 & 0.24 & 0.32 & & \\
\hline & Sox & 71.92 & 0.21 & 0.15 & & \\
\hline \multirow[t]{3}{*}{ Epi-5 $\beta$-campestanol } & ASE & 148.29 & 0.42 & 0.36 & \multirow[t]{3}{*}{0.35} & 0.40 \\
\hline & $\mathrm{BD}$ & 28.74 & 0.31 & 0.59 & & \\
\hline & Sox & 151.57 & 0.20 & 0.45 & & \\
\hline 24-Ethyl soprostenol & ASE & 100.34 & 0.70 & 1.01 & 0.15 & 0.10 \\
\hline & $\mathrm{BD}$ & 100.29 & 0.87 & 0.95 & & \\
\hline & Sox & 104.51 & 0.80 & 0.81 & & \\
\hline Epi-24-ethyl coprostenol & ASE & 103.96 & 0.41 & 0.44 & 0.15 & 0.08 \\
\hline & $\mathrm{BD}$ & 99.62 & 0.31 & 0.66 & & \\
\hline & Sox & 110.83 & 0.26 & 0.50 & & \\
\hline 24-Ethyl-coprostanol & ASE & 737.60 & 2.18 & 2.09 & 0.25 & 0.19 \\
\hline & $\mathrm{BD}$ & 737.29 & 1.69 & 3.06 & & \\
\hline & Sox & 760.43 & 1.36 & 1.27 & & \\
\hline Epi-24-ethyl-coprostanol & ASE & 760.95 & 2.68 & 1.12 & 0.33 & 0.24 \\
\hline & $\mathrm{BD}$ & 716.90 & 1.03 & 2.66 & & \\
\hline & Sox & 788.28 & 0.38 & 2.29 & & \\
\hline Campesterol & ASE & 0.50 & 0.55 & 3.21 & 0.40 & 0.33 \\
\hline & BD & 0.15 & 1.18 & 2.24 & & \\
\hline & Sox & 0.42 & 2.59 & 3.18 & & \\
\hline Campestanol & ASE & 213.06 & 0.92 & 1.02 & 0.09 & 0.03 \\
\hline & BD & 201.65 & 0.71 & 0.97 & & \\
\hline & Sox & 218.65 & 0.75 & 1.01 & & \\
\hline Stigmasterol & ASE & 27.77 & 2.25 & 2.42 & 0.06 & 0.05 \\
\hline & $\mathrm{BD}$ & 30.19 & 2.54 & 2.50 & & \\
\hline & Sox & 25.37 & 2.26 & 2.22 & & \\
\hline$\beta$-Sitosterol & ASE & 249.28 & 10.00 & 10.64 & 0.05 & 0.03 \\
\hline & $\mathrm{BD}$ & 236.98 & 9.78 & 10.80 & & \\
\hline & Sox & 249.95 & 9.87 & 10.51 & & \\
\hline Stigmastanol & ASE & 642.81 & 4.60 & 4.98 & 0.10 & 0.02 \\
\hline & $\mathrm{BD}$ & 617.22 & 3.57 & 4.22 & & \\
\hline & Sox & 665.26 & 4.21 & 5.15 & & \\
\hline
\end{tabular}


Table 4 The results of the ANOVA for the steroid biomarkers, showing any significant differences between method, sample type, and if there was any interaction effect between the two. The

\begin{tabular}{cllllll}
\hline Steroid & $\begin{array}{l}\text { Method } F \\
\text { value }\end{array}$ & $\begin{array}{l}\text { Method } P \\
\text { value }\end{array}$ & $\begin{array}{l}\text { Type } F \\
\text { value }\end{array}$ & $\begin{array}{l}\text { Type } P \\
\text { value }\end{array}$ & $\begin{array}{l}\text { Interaction effect } F \\
\text { value }\end{array}$ & $\begin{array}{l}\text { Interaction effect } P \\
\text { value }\end{array}$ \\
\hline Coprostanol & 1.8 & 0.194 & 240.2 & $<0.001$ & 1.49 & 0.246 \\
Epi-coprostanol & 0.53 & 0.599 & 156.47 & $<0.001$ & 1.83 & 0.168 \\
Cholesterol & 0.67 & 0.524 & 358.33 & $<0.001$ & 0.86 & 0.509 \\
5 $\alpha$-Cholestanol & 0.89 & 0.427 & 295.52 & $<0.001$ & 0.51 & 0.73 \\
5 3-Campestanol & 0.35 & 0.712 & 57.67 & $<0.001$ & 1.42 & 0.267 \\
Epi-5ß-campestanol & 0.43 & 0.657 & 202.91 & $<0.001$ & 1.11 & 0.384 \\
24-Ethyl coprostenol & 0.14 & 0.872 & 194.49 & $<0.001$ & 0.45 & 0.771 \\
Epi-24-ethyl coprostenol & 0.61 & 0.555 & 201.98 & $<0.001$ & 2.8 & 0.057 \\
24-Ethyl-coprostanol & 1.23 & 0.317 & 108.93 & $<0.001$ & 0.75 & 0.572 \\
Epi-24-ethyl-coprostanol & 0.91 & 0.419 & 72.82 & $<0.001$ & 3.27 & 0.035 \\
Campesterol & 1.41 & 0.27 & 5.26 & 0.048 & 1.16 & 0.36 \\
Campestanol & 3.45 & 0.054 & 576.87 & $<0.001$ & 1.72 & 0.19 \\
Stigmasterol & 2.24 & 0.135 & 290.38 & $<0.01$ & 0.17 & 0.952 \\
$\beta$-Sitosterol & 0.15 & 0.861 & 593.47 & $<0.001$ & 0.24 & 0.912 \\
Stigmastanol & 15.28 & $<0.001$ & 307.42 & $<0.001$ & 2.31 & 0.097 \\
\hline
\end{tabular}

variance ratio ( $F$ value) of each is also shown. Significant results $(P=\leq 0.05)$ are highlighted in italics
Fig. 4b; those for the types analysis (Fig. 4a) suggest a very strong discrimination, almost entirely associated with the difference between slurry and the other two types - in both cases, it is only the first component on

Table 5 PCA loadings (contributions) of each response variable to PC1 $(91.67 \%)$ and PC2 $(4.67 \%)$. The first 2 principal components explained $96.34 \%$ of the variance

\begin{tabular}{llr}
\hline Steroid & PC1 & PC2 \\
\hline Campestanol & 0.26858 & 0.05759 \\
Stigmastanol & 0.26842 & 0.05908 \\
Epi-24-ethyl-coprostenol & 0.26818 & 0.0696 \\
24-Ethyl-coprostenol & 0.2677 & 0.04183 \\
$\beta$-Sitosterol & 0.26745 & 0.04152 \\
5a-Cholestanol & 0.26738 & 0.08819 \\
Epi-Coprostanol & 0.26701 & 0.06036 \\
24-Ethyl-coprostanol & 0.26548 & 0.04416 \\
Stigmasterol & 0.26405 & -0.01611 \\
Coprostanol & 0.26351 & 0.05387 \\
5ß-Campestanol & 0.26346 & -0.02816 \\
Epi-24-ethyl-coprostanol & 0.26145 & -0.06337 \\
Cholesterol & 0.25299 & 0.03046 \\
Epi-5ß-campestanol & 0.24878 & 0.14047 \\
Campesterol & -0.15687 & 0.97102 \\
\hline
\end{tabular}

which there is any discrimination. For the types analysis, there was a strong negative contribution of campestanol (with higher values apparently associated with higher values of soil and both) and a strong positive contribution of stigmastanol (where higher values are logically associated with the slurry type). Between PCA and CVA, it was possible to differentiate clearly between the slurry and soil/both sample types. However, whilst CVA shows a slight non-significant difference between soil and both, the combination of PCA and CVA were not capable of discriminating between the two sample types.

\section{Discussion}

\subsection{Steroid Characterisation}

Many of the steroids identified in this study have been previously identified in faecal samples (Leeming et al. 1996; Bull et al. 2002), although the total and individual steroidal content of agricultural animal faeces varies within the literature (Leeming et al. 1996; Tyagi et al. 2007; Prost et al. 2017). This could be due to differences in animal diet and there being no single methodology for 
Fig. 3 The principal components biplot for the steroidal analyses. The grouping factor was the method (ASE, black circle; Bligh and Dyer, grey circle; Soxhlet, white circle). Steroids: $5 \beta$ campestanol, coprostanol, 24ethyl-coprostanol, epicoprostanol, epi-24-ethylcoprostenol, $5 \alpha$-cholestanol, campestanol, stigmastanol, stigmasterol, 24-ethylcoprostenol, cholesterol, and $\beta$ sitosterol are not labelled due to the proximity of their markers

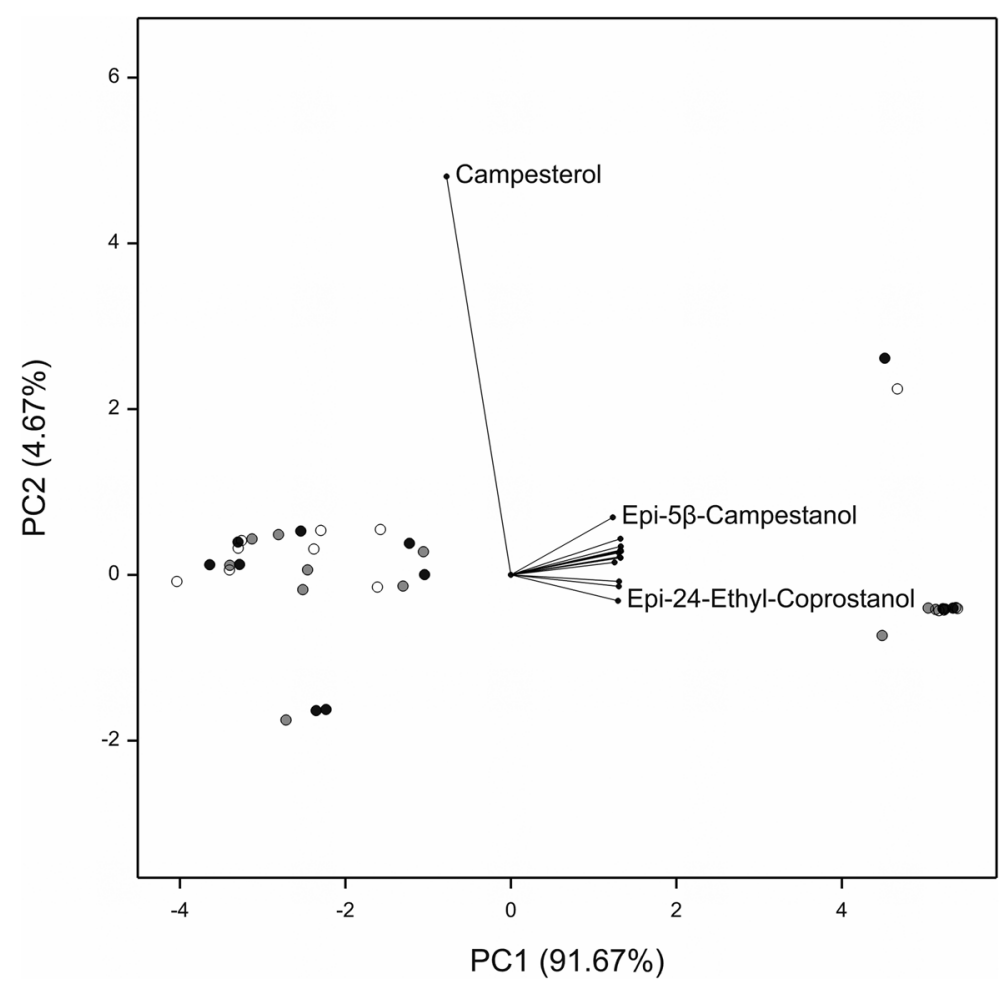

their analysis which makes direct comparisons more problematic.

However, there is still a general trend that can be observed, such as predominating steroids and general steroidal content differences between species (Prost et al. 2017). These include coprostanol predominating human faeces compared with 24-ethyl-coprostanol dominating herbivorous faeces. Also, herbivorous faecal content is predominantly made up of phytosterols (stigmasterol, $\beta$-sitosterol, 24-ethyl-coprostanol, epi24-ethyl-coprostanol, and $5 \alpha$-stigmastanol). In the literature, these usually comprise between 64 and $89 \%$ of the total contents of steroids (Prost et al. 2017) which reflects the plant-based diet of herbivores. This corresponds with results in this study since $68 \%$ of the total steroids were phytosterols.

Some steroids are also widely found within the environment including some that are present in both animals and plants (cholesterol) and phytosterols found in higher plants (campesterol, stigmasterol and $\beta$-sitosterol) (Furtula et al. 2012; Murtaugh and Bunch 1967; WenYen and Meinschein 1976). Accordingly, steroidal presence and values cannot be used alone. Leeming et al. (1996) determined the steroid distributions and concentrations in animal faeces and noticed variations in these steroid profiles depending on their source. As such, it was noted that ratios of these steroids can be used as more specific faecal indicators.

An additional complication is that these steroids are present in different ratios in many types of faeces. It has been established though, that by calculating the relative ratios of epi-coprostanol to 24-ethyl-coprostanol (ratio 1) (Leeming et al. 1996) or coprostanol to coprostanol + 24-ethyl-coprostanol (ratio 2) (Leeming et al. 1997; Harrault et al. 2019), it is possible to distinguish between human and herbivorous faecal matter (Leeming et al. 1996). The steroids 24-ethyl-coprostanol and epi24-ethyl-coprostanol were indeed present in all samples, and as shown in Table 3 were on average highest in slurry samples and in similar amounts within soil and both types (though with both having marginally higher levels though not significantly). When using the ratios developed by Leeming et al. (1996, 1997), it was noted that for ratio 1 , the average values were 0.1 for slurry, 0.1 for the soil, and 0.2 for both; for ratio 2 , the corresponding ratios were 0.3 for slurry, 0.2 for soil, and 0.3 for both. With regard to ratio 1 , values $\sim 2.8$ indicate human faeces, whereas $0-1.2$ indicates animals (Leeming et al. 1997). This puts the slurry sample within the expected range (expected as this is cattle slurry) and 

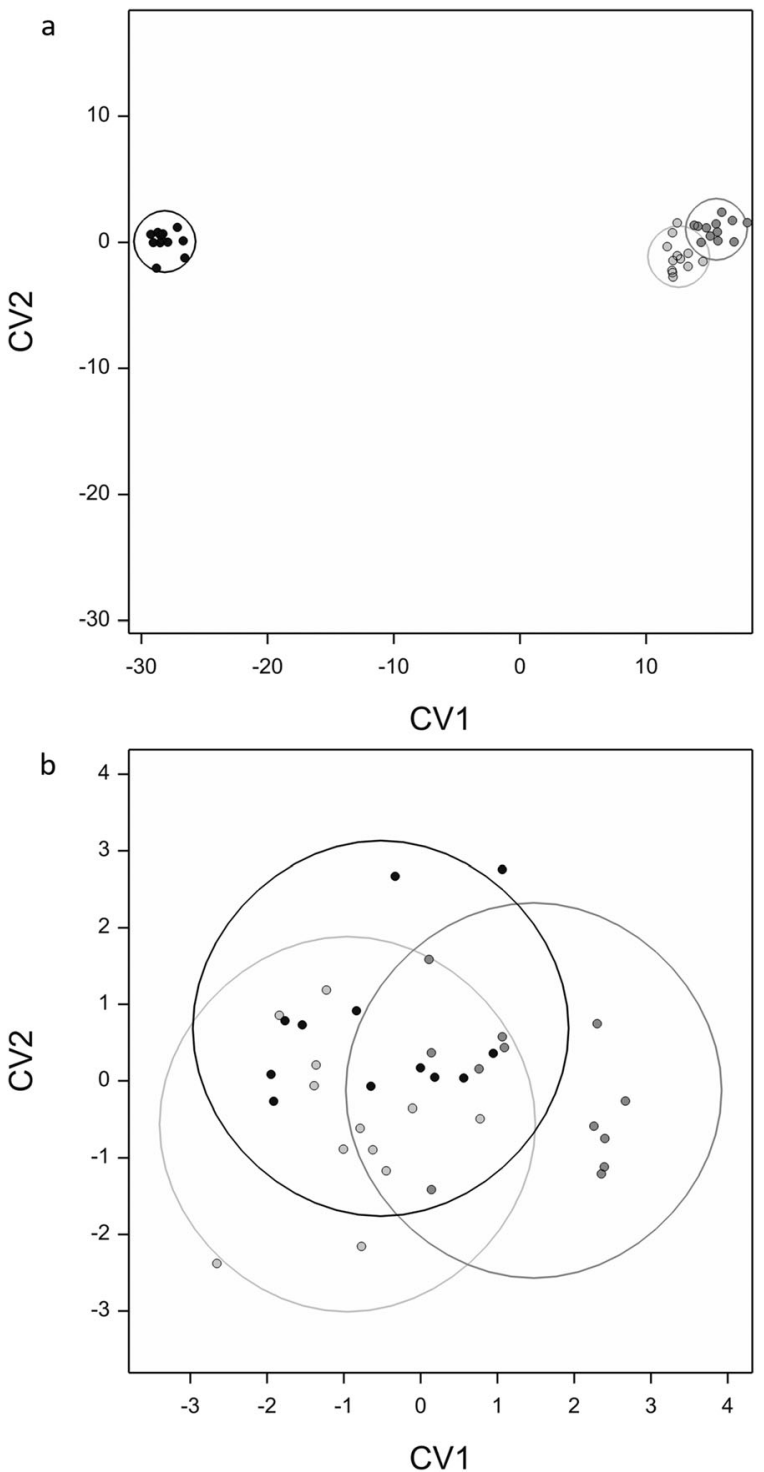

Fig. 4 The canonical variate graphs for the steroidal analyses. The graph on the top (a) shows the significant groupings created when using type (both, light grey circle; slurry, black circle; soil, dark grey circle) as the grouping factor. The graph on the bottom (b) shows the slight, but not significant groupings when using the method as the grouping factor (ASE, black circle; Bligh and Dyer, dark grey circle; Soxhlet, light grey circle)

the soil also (similarly unsurprising due to the past use of the study field). The both ratio was high, though not high enough to indicate human faecal matter. Exclusion of an unusually low 24-ethyl-coprostanol content reduced this ratio to 1.3 and closer to the expected value. For ratio 2 , values $<0.38$ indicate herbivore faeces, and values $>0.73$ indicate human faeces. In this study, the average values for slurry, soil, and both all fall into the expected category indicating herbivorous faeces/ contamination.

Regarding sample type, on average, slurry contained approximately 1000 -fold the amount of steroids than the other two sample types. This high value corresponds with the existing literature, as well as the fact that the samples are predominated by 24-ethyl-coprostanol (Prost et al. 2017). This corresponds with the findings of past studies regarding the dominant steroids in ruminant faeces (Leeming et al. 1996; Bull et al. 2002; Gill et al. 2010).

\subsection{Extraction Method Comparison}

As shown in Table 4, there was no significant difference $(P<0.05)$ in extraction method, except for one steroid (stigmastanol). This steroid also has the highest variance ratio (15.28) compared with the other steroids. Stigmastanol is a phytosterol, the product of the reduction of $\beta$-sitosterol and the biohydrogenation of stigmasterol by bacteria. However, as a $5 \mathrm{a}$-stanol, it is the product of biohydrogenation from microorganisms found within the environment, not within the gut of higher organisms. These are the $5 \beta$-stanols (Prost et al. 2017). As such, stigmastanol is not useful as a biomarker of cattle faeces, alone or in any ratio and so can be excluded from further method interpretation (at least for biomarker studies).

However, from the canonical variate analysis (Fig. 4b), there are visible groupings and separations between the methods, though this is very weak. It was observed that all of the methods had similarly high yields of steroids although ASE returned the highest yields in the majority of these cases, followed by Soxhlet and the BD. This indicates that ASE may be marginally more efficient, with BD being the least efficient. Previous work has, however, reported that ASE has marginally lower efficiencies than Soxhlet (Shen and Shao 2005) and that BD performs lower than Soxhlet also (Shah et al. 2006).

Whilst solid media were sampled in this study, it may be the need of other studies to sample other media. In previous studies (Isobe et al. 2004; Cordeiro et al. 2008; Gómez et al. 2012; Rontani et al. 2014), extraction has been completed using water filtered through glass fibre filters with the resultant suspended sediments being analysed. The collection and analysis of water samples for dissolved concentrations is not typically undertaken as previous studies have reported that $>95 \%$ of sterols 
are typically associated with the suspended sediment fraction of water samples (Isobe et al. 2002). In the aforementioned studies, the extraction method used was typically BD. However, in knowing that ASE is just as, if not more, efficient than BD for extracting lipids, there should be no technical difficulty in analysing suspended sediment media with ASE.

A recommendation from this study will be to determine the combination of resources required for lipid biomarker extraction and the nature of the solid media being investigated prior to full experimental work. Nevertheless, there is confidence from the robust analysis here that ASE can be used in the full characterisation of steroids for lipid biomarker research as appropriate and as an alternative in laboratories ordinarily using other methods. This is an important consideration, for example when laboratories are moving from one method to another and where some confidence in analysis continuity is required. Here, the results provide a full characterisation of steroid biomarkers for onward use in diffuse faecal pollution studies.

\section{Conclusions}

Based on this study of three lipid extraction methods applied to slurry/soil samples, it can be concluded that there is no significant difference in the data generated by the extraction method used, regardless of the type of sample used, for each steroid extracted. This, being the case, choice of lipid extraction method for steroidal analyses becomes a choice based on economic factors, such as how resource (time/expense) intensive the method is and how much solvent is expended. It is clear, however, that based on these considerations, ASE is the more attractive method, as it is the quickest, least expensive, and consumes the smallest volume of solvents out of the three methods investigated.

Acknowledgements We acknowledge the Walsh Fellowship (Ref: 2016115) provided by Teagasc to Ulster University, the Teagasc Agricultural Catchments Programme (funded by the Irish Department of Agriculture, Food and the Marine), and Rothamsted Research for part funding this research. We thank the farmer for providing slurry, as well as Sarah Gilhespy, Karen Saunders, Rachel Matthews, and Andrew Mead at Rothamsted Research for their invaluable help. Rothamsted Research receives strategic funding from UKRI-BBSRC (UK Research and Innovation-Biotechnology and Biological Sciences Research Council) and the contribution to this work by ALC was supported by the Soil to Nutrition strategic programme under project 3 (grant award BBS/E/C/000I0330).
Code Availability $\quad$ Data were analysed on Genstat 19.

Funding Funding came from the Teagasc Agricultural Catchments Programme and Rothamsted Research.Data AvailabilityData will be available on request.

\section{Compliance with Ethical Standards}

Conflict of Interest The authors declare that they have no conflict of interest.

Open Access This article is licensed under a Creative Commons Attribution 4.0 International License, which permits use, sharing, adaptation, distribution and reproduction in any medium or format, as long as you give appropriate credit to the original author(s) and the source, provide a link to the Creative Commons licence, and indicate if changes were made. The images or other third party material in this article are included in the article's Creative Commons licence, unless indicated otherwise in a credit line to the material. If material is not included in the article's Creative Commons licence and your intended use is not permitted by statutory regulation or exceeds the permitted use, you will need to obtain permission directly from the copyright holder. To view a copy of this licence, visit http://creativecommons.org/licenses/by/4.0/.

\section{References}

Arnscheidt, J., Jordan, P., Li, S., McCormick, S., McFaul, R., McGrogan, H. J., Neal, M., \& Sims, J. T. (2007). Defining the sources of low-flow phosphorus transfers in complex catchments. Science of the Total Environment, 382(1), 1-13.

Axelsson, M., \& Gentili, F. (2014). A single-step method for rapid extraction of total lipids from green microalgae. PLoS One, 9, e89643.

Balasubramanian, R. K., Doan, T. T. Y., \& Obbard, J. P. (2013). Factors affecting cellular lipid extraction from marine microalgae. Chemical Engineering Journal, 215-216, 929-936.

Berndmeyer, C., Thiel, V., \& Blumenberg, M. (2014). Test of microwave, ultrasound and Bligh \& Dyer extraction for quantitative extraction of bacteriohopanepolyols (BHPs) from marine sediments. Organic Geochemistry, 68, 90-94.

Bligh, E. G., \& Dyer, W. J. (1959). A rapid method of total lipid extraction and purification. Canadian Journal of Biochemistry and Physiology, 37(8), 911-917.

Breil, C., Meullemiestre, A., Vian, M., \& Chemat, F. (2016). Bio-based solvents for green extraction of lipids from oleaginous yeast biomass for sustainable aviation biofuel. Molecules, 21, 196.

Breil, C., Abert Vian, M., Zemb, T., Kunz, W., \& Chemat, F. (2017). "Bligh and Dyer" and Folch methods for solidliquid-liquid extraction of lipids from microorganisms. Comprehension of solvatation mechanisms and towards substitution with alternative solvents. International Journal of Molecular Sciences, 18(4), 708.

Brennan, R. B., Healy, M. G., Grant, J., Ibrahim, T. G., \& Fenton, O. (2012). Incidental phosphorus and nitrogen loss from 
grassland plots receiving chemically amended dairy cattle slurry. Science of the Total Environment, 441, 132-140.

Bull, I. D., Lockheart, M. J., Elhmmali, M. M., Roberts, D. J., \& Evershed, R. P. (2002). The origin of faeces by means of biomarker detection. Environment International, 27(8), 647-654.

Bull, I., Elhmmali, M., Roberts, D., \& Evershed, R. (2003). The application of steroidal biomarkers to track the abandonment of a roman wastewater course at the Agora. Archaeometry, 45(1), 149-161.

Caprioli, G., Giusti, F., Ballini, R., Sagratini, G., Vila-Donat, P., Vittori, S., \& Fiorini, D. (2016). Lipid nutritional value of legumes: evaluation of different extraction methods and determination of fatty acid composition. Food Chemistry, 192, 965-971.

Cescut, J., Severac, E., Molina-Jouve, C., \& Uribelarrea, J.-L. (2011). Optimizing pressurized liquid extraction of microbial lipids using the response surface method. Journal of Chromatography A, 1218, 373-379.

Chitescu, C. L., Oosterink, E., de Jong, J., \& Stolker, A. A. M. (2012). Ultrasonic or accelerated solvent extraction followed by U-HPLC-high mass accuracy MS for screening of pharmaceuticals and fungicides in soil and plant samples. Talanta, 88, 653-662.

Cordeiro, L., Carreira, R., \& Wagener, A. (2008). Geochemistry of fecal sterols in a contaminated estuary in southeastern Brazil. Organic Geochemistry, 39(8), 1097-1103.

Fahy, E., Subramaniam, S., Murphy, R. C., Nishijima, M., Raetz, C. R., Shimizu, T., Spener, F., van Meer, G., Wakelam, M. J., \& Dennis, E. A. (2009). Update of the LIPID MAPS comprehensive classification system for lipids. Journal of Lipid Research, 50(supplement), S9-S14.

Furtula, V., Liu, J., Chambers, P., Osachoff, H., Kennedy, C., \& Harkness, J. (2012). Sewage treatment plants efficiencies in removal of sterols and sterol ratios as indicators of fecal contamination sources. Water, Air, \& Soil Pollution, 223(3), 1017-1031.

Giergielewicz-Mozajska, H., Dabrowski, L., \& Namiesnik, J. (2001). Accelerated solvent extraction (ASE) in the analysis of environmental solid samples - some aspects of theory and practice. Critical Reviews in Analytical Chemistry, 31, 149-165.

Gill, F. L., Dewhurst, R. J., Dungait, J. A., Evershed, R. P., Ives, L., Li, C. S., Pancost, R. D., Sullivan, M., Bera, S., \& Bull, I. D. (2010). Archaeol-a biomarker for foregut fermentation in modern and ancient herbivorous mammals? Organic Geochemistry, 41(5), 467-472.

Gómez, M., Herrera, S., Solé, D., García-Calvo, E., \& FernándezAlba, A. (2012). Spatio-temporal evaluation of organic contaminants and their transformation products along a river basin affected by urban, agricultural and industrial pollution. Science of the Total Environment, 420, 134-145.

Grima, E. M., Medina, A. R., Giménez, A. G., Pérez, J. S., Camacho, F. G., \& Sánchez, J. G. (1994). Comparison between extraction of lipids and fatty acids from microalgal biomass. Journal of the American Oil Chemists' Society, 71, 955-959.

Grimalt, J. O., Fernandez, P., Bayona, J. M., \& Albaiges, J. (1990). Assessment of fecal sterols and ketones as indicators of urban sewage inputs to coastal waters. Environmental Science and Technology, 24(3), 357-363.

Harrault, L., Milek, K., Jardé, E., Jeanneau, L., Derrien, M., \& Anderson, D. G. (2019). Faecal biomarkers can distinguish specific mammalian species in modern and past environments. PLoS One, 14(2).

Huang, W.-Y., \& Meinschein, W. G. (1976). Sterols as source indicators of organic materials in sediments. Geochimica et Cosmochimica Acta, 40(3), 323-330.

Hussain, J., Ruan, Z., Nascimento, I. A., Liu, Y., \& Liao, W. (2014). Lipid profiling and corresponding biodiesel quality of Mortierella isabellina using different drying and extraction methods. Bioresource Technology, 169, 768-772.

Isobe, K., Tarao, M., Zakaria, M., Chiem, N., Minh, L., \& Takada, H. (2002). Quantitative application of fecal sterols using gas chromatography-mass spectrometry to investigate fecal pollution in tropical waters: Western Malaysia and Mekong Delta, Vietnam. Environmental Science \& Technology, 36(21), 4497-4507.

Isobe, K. O., Tarao, M., Chiem, N. H., Minh, L. Y., \& Takada, H. (2004). Effect of environmental factors on the relationship between concentrations of coprostanol and fecal indicator bacteria in tropical (Mekong Delta) and temperate (Tokyo) freshwaters. Applied and Environmental Microbiology, 70(2), 814-821. https://doi.org/10.1128/aem.70.2.814-821.2004.

Jang, J., Hur, H. G., Sadowsky, M. J., Byappanahalli, M. N., Yan, T., \& Ishii, S. (2017). Environmental Escherichia coli: ecology and public health implications - a review. Journal of Applied Microbiology, 123(3), 570-581.

Jansen, B., Nierop, G. J. N., Kotte, M. C., de Voogt, P., \& Verstraten, J. M. (2006). The applicability of accelerated solvent extraction (ASE) to extract lipid biomarkers from soils. Applied Geochemistry, 21(6), 1006-1015.

Jardé, E., Gruau, G., \& Jaffrezic, A. (2009). Tracing and quantifying sources of fatty acids and steroids in amended cultivated soils. Journal of Agricultural and Food Chemistry, 57(15), 6950-6956.

Kolm, H., Gomes, K., Ishii, F., \& Martins, C. (2018). An integrated appraisement of multiple faecal indicator bacteria and sterols in the detection of sewage contamination in subtropical tidal creeks. International Journal of Hygiene and Environmental Health, 221(7), 1032-1039.

Lee, S. J., Yoon, B.-D., \& Oh, H.-M. (1998). Rapid method for the determination of lipid from the green alga Botryococcus braunii. Biotechnology Techniques, 12, 553-556.

Lee, J.-Y., Yoo, C., Jun, S.-Y., Ahn, C.-Y., \& Oh, H.-M. (2010). Comparison of several methods for effective lipid extraction from microalgae. Bioresource Technology, 101, S75-S77.

Leeming, R., Ball, A., Ashbolt, N., Jones, G., \& Nichols, P. (1994). Distinguishing between human and animal sources of faecal pollution. Chemistry in Australia, 61, 434- 435.

Leeming, R., Ball, A., Ashbolt, N., \& Nichols, P. (1996). Using faecal sterols from humans and animals to distinguish faecal pollution in receiving waters. Water Research, 30(12), 28932900.

Leeming, R., Latham, V., Rayner, M. and Nichols, P. (1997). Detecting and distinguishing sources of sewage pollution in Australia inland and coastal waters and sediments. Molecular Markers in Environmental Geochemistry, pp.306-319.

Leeming, R., Bate, N., Hewlett, R., \& Nichols, P. (1998). Discriminating faecal pollution: a case study of storm water entering port Phillip Bay, Australia. Water Science and Technology, 38, 15-22. 
Luque de Castro, M. D., \& Priego-Capote, F. (2010). Soxhlet extraction: past and present panacea. Journal of Chromatography A, 1217, 2383-2389.

Luque-Garcia, J. L., \& De Castro, M. L. (2004). Ultrasoundassisted soxhlet extraction: an expeditive approach for solid sample treatment: application to the extraction of total fat from oleaginous seeds. Journal of Chromatography A, 1034(1-2), 237-242.

Lyons, B., Devlin, M., Abdul Hamid, S., Al-Otiabi, A., Al-Enezi, M., Massoud, M., Al-Zaidan, A., Smith, A., Morris, S., Bersuder, P., Barber, J., Papachlimitzou, A., \& Al-Sarawi, H. (2015). Microbial water quality and sedimentary faecal sterols as markers of sewage contamination in Kuwait. Marine Pollution Bulletin, 100(2), 689-698.

Medina, A. L., da Silva, M. A. O., de Sousa Barbosa, H., Arruda, M. A. Z., Marsaioli, A., \& Bragagnolo, N. (2015). Rapid microwave assisted extraction of meat lipids. Food Research International, 78, 124-130.

Mudge, S. M., \& Duce, C. E. (2005). Identifying the source, transport path and sinks of sewage derived organic matter. Environmental Pollution, 136(2), 209-220.

Mudge, S. M., Bebianno, M. J. A. F., East, J. A., \& Barreira, L. A. (1999). Sterols in the Ria Formosa lagoon, Portugal. Water Research, 33(4), 1038-1048.

Murtaugh, J.J. \& Bunch, R.L. (1967). Sterols as a measure of fecal pollution. Journal of the Water Pollution Control Federation, 39(3), 404-409.

Nash, D., Leeming, R., Clemow, L., Hannah, M., Halliwell, D., \& Allen, D. (2005). Quantitative determination of sterols and other alcohols in overland flow from grazing land and possible source materials. Water Research, 39(13), 2964-2978.

Ndiomu, D. P., \& Simpson, C. F. (1988). Some applications of supercritical fluid extraction. Analytica Chimica Acta, 213, 237-247.

Norris, C. E., Dungait, J. A. J., Joynes, A., \& Quideau, S. A. (2013). Biomarkers of novel ecosystem development in boreal forest soils. Organic Geochemistry., 64, 9-18.

Prost, K., Birk, J. J., Lehndorff, E., Gerlach, R., \& Amelung, W. (2017). Steroid biomarkers revisited-improved source identification of faecal remains in archaeological soil material. PloS One, 12(1), e0164882.

Prost, K., Bradel, P. L., Lehndorff, E., \& Amelung, W. (2018). Steroid dissipation and formation in the course of farmyard manure composting. Organic Geochemistry, 118, 47-57.

Puttock, A., Dungait, J. A. J., Macleod, C. J. A., Bol, R., \& Brazier, R. E. (2014). Woody plant encroachment into grasslands leads to accelerated erosion of previously stable organic carbon from dryland soils. Journal of Geophysical Research
Biogeosciences, 119, 2345-2357. https://doi.org/10.1002 /2014JG002635.

Richter, B. E., Jones, B. A., Ezzell, J. L., Porter, N. L., Avdalovic, N., \& Pohl, C. (1996). Accelerated solvent extraction: a technique for sample preparation. Analytical Chemistry, 68(6), 1033-1039.

Rontani, J.-F., Charrière, B., Sempéré, R., Doxaran, D., Vaultier, F., Vonk, J. E., \& Volkman, J. K. (2014). Degradation of sterols and terrigenous organic matter in waters of the Mackenzie shelf, Canadian Arctic. Organic Geochemistry, 75, 61-73.

Ryckebosch, E., Muylaert, K., \& Foubert, I. (2012). Optimization of an analytical procedure for extraction of lipids from microalgae. Journal of the American Oil Chemists' Society, 89, 189-198.

Shah, V. K. G., Dunstan, H., \& Taylor, W. (2006). An efficient diethyl ether-based soxhlet protocol to quantify faecal sterols from catchment waters. Journal of Chromatography A, 1108(1), 111-115.

Shen, J., \& Shao, X. (2005). A comparison of accelerated solvent extraction, Soxhlet extraction, and ultrasonic-assisted extraction for analysis of terpenoids and sterols in tobacco. Analytical and Bioanalytical Chemistry, 383(6), 1003-1008.

Sheng, J., Vannela, R., \& Rittmann, B. E. (2011). Evaluation of methods to extract and quantify lipids from Synechocystis PCC 6803. Bioresource Technology, 102, 1697-1703.

Teo, C. L., \& Idris, A. (2014). Enhancing the various solvent extraction method via microwave irradiation for extraction of lipids from marine microalgae in biodiesel production. Bioresource Technology, 171, 477-481.

Tyagi, P., Edwards, D. R., \& Coyne, M. S. (2007). Use of selected chemical markers in combination with a multiple regression model to assess the contribution of domesticated animal sources of fecal pollution in the environment. Chemosphere, 69(10), 1617-1624.

Unno, T., Staley, C., Brown, C. M., Han, D., Sadowsky, M. J., \& Hur, H. G. (2018). Fecal pollution: new trends and challenges in microbial source tracking using next-generation sequencing. Environmental Microbiology, 20(9), 3132-3140.

Wen-Yen, H., \& Meinschein, W. G. (1976). Sterols as source indicators of organic materials in sediments. Geochimica et Cosmochimica Acta, 40(3), 323-330.

Publisher's Note Springer Nature remains neutral with regard to jurisdictional claims in published maps and institutional affiliations. 